\title{
ENERGY SAFETY OF UKRAINE: RUSSIAN FACTOR
}

\section{Dr Olga BRUSYLOVSKA,}

Professor,

Institute of Social Sciences, Odessa National Mechnikov University, Odessa, Ukraine

brusylovska@onu.edu.ua

\begin{abstract}
A number of political events in Ukraine at the end of 2013 and early in 2014 led to the frequent use of the term "the Ukrainian crisis". It had impact not only on Ukraine's interaction with the EU and the RF, but also in reviewing of the interstate cooperation of the Western countries and their allies with the RF. As a result of sanctions imposition against the RF because of annexation of Crimea, in 2015 the Russian government took the decision to amend the energy strategy for the period until 2035, in order to maintain the strategic development of the Russian energy sector. To that the majority of countries it was explained as a try to conduct the diversification of energy structure, to develop the not-carbohydrate energy sources and to use nonconventional kinds of fuel. The energy resources are used by Russia as one of the tools of conducting hybrid war against Ukraine and the energy infrastructure became an object of foreign conquest. In future, Russia will try to use its monopoly position in relation to the possession and producing of energy resources as to bring pressure upon both, Ukraine and the EU. In long-term Ukraine and the EU have a diversification opportunity in respect of the energy resources through the development of the nuclear energy production, a use of the alternative energy sources, a technological modernization of the energy sector for extraction of slate gas, a rebuilding of the transport and energy infrastructures.
\end{abstract}

Keywords: Energy Strategy, Ukraine, the Russian Federation

From the theoretical perspective of international relations, the question of interconnection between energy diplomacy, energy security, energy policy and energy 
independence of states, was not explored enough until today. The neorealist conceptual approach to the energy dimension of the international relations is focused on the global, regional and interstate conflicts in the energy sphere, which is limited by the research of means of the energy transnational, intercompany and state-enterprise interaction, the defining of the peculiarities of the political distribution of power, the location and value of the energy resources. The sphere of Ukraine's national interests includes a development of equality in rights in regard to the partnership at the level Ukraine - the Russian Federation - the EU, a creation of the competitive international and regional environments in public authorities domain, Russia's keeping to the European Energy Charter Treaty, the liberalization of the Russian power market and the real diversification of power resources.

\section{History and present stage of bilateral interaction of Ukraine with the} Russian Federation in energy sphere: main documents

The Ukrainian - Russian energy relations are based on the transit of energy carriers. Unfortunately, for Ukraine it is not possible to use an advantage of the transit state, owing to permanent changes at the international, regional and internal energy market, an imperfect management of the economy and a non-transparency of public authorities.

Since 1990s "Gazprom" was constantly manipulating the rates (tariffs) for gas transit. So, the import to the Ukrainian gas market of non-Russian fuel was economically unprofitable; increased debts of Ukraine for the energy resources; blocked export of the Caspian oil-and-gas resources.

As a result, this led to the strengthening of political, economic and security sensibility of Ukraine and dependence on the Russian Federation, the competitiveness deterioration of the Ukrainian production, the disproportional attraction of the Western and Russian companies to privatization in the Ukrainian transport and processing enterprises in oil-and-gas area and to the close-out of the project "Euro-Asian corridor" for transportation 
of the Caspian oil. It also didn't solve the problem of diversification of Ukraine's gas supplies (Pirozhkov, 2001).

At the beginning of 2000s, the Ukrainian experts specified a number of threats to the national interests of Ukraine in energy sphere, in the context of the bilateral interaction with the Russian Federation. In particular, scientists have defined that the external energy policy of the Russian Federation is two-level: at the first level the aim is a targeted squeeze on the political management of CIS countries, concerning the transfer into ownership of the Russian companies of the gas-transport infrastructure in repayment of debts or the enterprises of oil refining and petro-chemistry under obligations to increase oil delivery; at the second level, the pursued goal is to form the diversification systems of the main pipelines and terminals of the RF and to reduce the dependence of deliveries from the gas infrastructures of the post-Soviet countries. Such approaches are equitable only to interests of Russia, which tried to force Ukraine to refuse from its own energy policy; as a consequence it resulted in the growth of strategic energy dependence of Ukraine on Russia, freezing the project of Euro-Asian petro-transport corridor (Odessa - Gdansk) and an acceptance of the supervising positions in the Ukrainian oil refining and petro-chemistry fields (Pirozhkov, 2001).

At the beginning 2014, Ukraine needed to determine its national interests in the energy sphere, but it became one of the reasons of an aggravation of the mutual relations. Nowadays, Ukraine should modernize its own gas-transport system, but already without the Russian Federation, keep the status of the transit state due to an attraction of the European and American financial assets, and also carry out the internal reforms in energy sector (Mazurec and Ryzhkov, 2014, p. 63).

The interaction in the oil-and-gas area is now notable by the simultaneous dependence both from the political and economic forces, because of the aggressive policy of the Russian Federation against Ukraine. Since the Russian annexation of a part of the Ukrainian territory (Crimea), their energy cooperation has been adjusted by the 26 general 
Issue no. 22/2017

documents.

In the energy sector, the following documents were signed: The cooperation agreement on the development of fuel and energy complexes of Ukraine and the Russian Federation (1994); Agreements of delivery of natural gas and its transit through the territory of Ukraine (1992); Cooperation on the development of the oil and gas industry (1993); Export of the Russian natural gas to Ukraine and its transit through the territory of Ukraine to the European countries (1994); Agreement about mutual offset of debts for the power resources and materials (1997; came into force of 1999); Guarantees of transit of the Russian natural gas territory of Ukraine (2000); Additional measures concerning maintenance of transit of natural gas along the territory of Ukraine (2001); Conditions of the reserve deliveries and payments of the Russian natural gas to Ukraine in 2001 (2000; came into force of 2002); Strategic cooperation in gas area (2002); Arrangements for the maintenance of the strategic cooperation in gas area (2004); The memorandum on the issues of establishment of the mutual relations between Ukraine and the Russian Federation in gas sphere (2000); The report between the Ukrainian State customs service and the State customs committee of the Russian Federation about interaction in terms of carrying out a control over energy carriers by the customs clearance (2002); The contract between the Ukrainian "Naftogas" and the Russian "Gazprom" on the volumes and conditions of natural gas transit along the territory of Ukraine from 2009 till 2012 (2009), regarding the purchase - sales of natural gas in 2009-2012; Addendum to the contract between "Naftogas" and "Gazprom" about purchase - sale of natural gas for the period between 2009-2019; Supplement to the treaty between "Naftogas" and "Gazprom" on the volumes and conditions of transit of gas through the territory of Ukraine in $2009-2019$ (2010). In the area of electric power industry exist such documents as the Agreements on the general production for the thermal power stations (1992) and about actions aimed at the maintenance of parallel work of the incorporated power system of Ukraine and the Unified power system of the Russian Federation (2012); Memorandums on cooperation are signed 
in the field of electric power industry between the Ministry of Fuel and Power of Ukraine and Russian Open Society "UES of Russia" (2001); Cooperation between the State enterprise "Power market", the State enterprise of the foreign trade activities "UkrInterEnergo" and Open Society "Inter RAT European Economic Community" (2010). There are the following documents in atomic engineering: Agreements on scientific, technical and economic cooperation in atomic engineering area (1993); Information interchange and cooperation in sphere of safety regulation of nuclear energy use for the peaceful purposes (2002); The contract between "Energoatom" and Open Society "TVEL", concerning the supply of nuclear fuel to the Ukrainian atomic power stations (2010); The memorandum between the Ministry of Power and the Coal Industry of Ukraine and the State Atomic Energy Corporation "Rosatom" on the integration and cooperation in the field of atomic energy use for the peaceful purposes (2012) (The MFA of Ukraine, 2016).

Until 2014, the Ukrainian - Russian relations in respect of the energy sector were based on the almost individual export of the Russian energy resources to the EU and Ukraine, where the last mentioned acted as the importer partner and transit state to the EU countries. Since 2014, the Ukrainian government, through initiation of contracts revision relating to the gas supplies to Ukraine and its transportation to European consumers, has been trying to minimize the political component of energy interaction. Therefore, "Naftogas" and "Gazprom" have applied to the Arbitration Institute of the Stockholm Chamber of Commerce with respect to the contract revision on gas supplies to Ukraine and in order to fill some strategic gaps on the contract of gas purchase and sales, and also concerning the contract on gas transit (the decision probably will be taken in March, 2017). The gas supplies from the EU help Ukraine to get rid of the overdependence on the Russian gas deliveries, in particular in $2015,37 \%$ of gas was imported from the Russian Federation. In opinion of experts, it provides an opportunity to inject liquidity of the Ukrainian market, to become more integrated to the European market and to raise the level of general safety (Naftogas of Ukraine, 2016). 


\section{Energy conflicts in the Ukrainian-Russian relations}

For a better understanding of the existing threats, in the relations with the Russian Federation in the energy sphere, we should analyse the reasons and effects of the bilateral energy conflicts.

The Ukrainian - Russian energy relations between 1993 and 2004 have been connected with the threats of "Gazprom", in point of the cessation of gas deliveries to Ukraine because of the debts. The Ukrainian side responded to this threat by blocking the transit corridors to Europe. As a result, Ukraine exchanged a part of the ships of the Black Sea fleet for remission of 800 million dollars of the gas debt (September, 1993).

The first bilateral gas agreement (1994) between Ukraine and the Russian Federation was signed after the separation of the Ukrainian and Russian energy systems. Its validity period ran until 2005. Meanwhile the re-export of the Russian gas from Ukraine's territory was forbidden, however, Ukraine was authorized to cover the gas debts because of "Gazprom" demands. Owing to an incurring of the next Ukrainian gas debts in 1995, the Russian Federation wanted that Ukraine transfers a part of ownership rights to its gas mains and oil refining enterprises, however, the sides agreed to work according to the schedule repayment.

During 1995-2009 the Ukrainian - Russian energy relations were developing at the level of the industrial and financial corporation "United energy systems of Ukraine", thus the integrator company "Republic", and in due course "Itera", engaged in the joint Ukrainian - Turkmen gas project, where the Russian Federation plays a role of the transit state. Since 1998 upon the governmental initiatives, the national joint-stock company "Petrogas", the competences of which lies in gas import to Ukraine, its transit along the territory of Ukraine and also the national extraction of energy carriers. In the intergovernmental gas agreement 2001 it was stipulated that the price for the Russian gas for Ukraine is fixed and the procedure of debt return should be conducted through the 
repayment of bonds over the period from 2004 to 2013 (Knyazhanskiy, 2016).

The next Ukrainian - Russian energy conflict of 2005-2006 took place after "the Orange Revolution" 2004, in the course of which Ukraine chose the pro-European foreign policy vector that resulted in the increase of the Russian energy pressure on Ukraine and hurt its ability of the Ukrainian metallurgical companies to compete, raising the price of gas. Besides, in December 2005, the interstate contract between Ukraine and Turkmenistan and the Russian Federation agreement, regarding the transit of the Turkmen terminated. Therefore, the short-term stop of gas supplies to Ukraine that also happened at the beginning of January, 2006, decreased its flows to Europe and led to the signing of a new contract. Since a change of the conditions for the gas supplies in 2006, the price for energy resources transit via Ukraine and the supplies for the internal consumption in particular, have been determined separately by the main permanent mediator company at the Ukrainian gas market "RosUkrEnergo", which is the unique Russian monopolist - supplier of carbohydrate power resources (Knyazhanskiy, 2016).

The next Ukrainian - Russian energy conflict 2008-2009 pushed the Ukrainian gastransport system to function in an independent mode and to transit its own resources to Europe, singing the annual contracts on gas supplies. The longstanding confrontation resulted in a signing of the Ukrainian - Russian gas agreements 2009, which stipulated that the direct deliveries from "Gazprom" to "Petrogas" would be proceed. According to the document "RosUkrEnergo", as the mediator-company was dissolving the constant formula of the price determination for the Russian gas had to be fixed, depending on the world price for oil and mineral oil. Ukraine was also obliged to redeem the Russian Federation 41.6 billion cubic metres of gas throughout the year, simultaneously holding to the condition that "Gazprom" undertakes commitments to transport via Ukraine no less than 20 billion cubic metres of gas. Consequently, the Kharkov accords were signed in 2010 . Ukraine received a 100 dollars discount for the Russian gas in exchange for the extension of the Russian lease on naval facilities in Sevastopol until 2042. So, the mid-annual price 
of the Russian gas for Ukraine in 2009 amounted to 228 dollars per 1000 cubic metres, whereas in 2012 was up to 440 dollars 1000 per cubic metres in view of the discount. Thus, Ukraine's duties even increased owing to the disregard of the contract provisions, connected with a gas shortage (Knyazhanskiy, 2016).

In 2014 the relations between Ukraine - the EU - the Russian Federation in the energy area involved other international actors such as the USA and Canada, as the potential exporters of the liquefied natural gas to Europe and Asian Pacific region, and also China, as the consumer of the Russian or American oil-and-gas resources.

A number of the internal political events, which took place in Ukraine at the end of 2013 and early in 2014, led to the frequent use of a term "the Ukrainian crisis". It had impact not only on the foreign policy, economic and energy spheres in Ukraine's interaction with the EU and the Russian Federation, but also in reviewing of the interstate cooperation of the Western countries and their allies with the Russian Federation, the restoration of mutual relations between the USA and Cuba and the cancellations of sanctions against Iran (Mazurec and Ryzhkov, 2014, p. 65).

The ordinary phenomenon of the Ukrainian - Russian relations is that even until now there are "gas wars". At the lowest temperatures, any reduction of pressure in the gastransport system can cause the short-term interruptions of fuel deliveries to the endconsumer. The Russian Federation resorted purposely for a couple of days to the cessation of fuel deliveries to the Ukrainian system, motivating that by Ukraine's unwillingness to turn to the market mechanisms of setting the gas prices. The Russian Federation faulted Ukraine for the selection of gas, which intended for the European consumers, forming a negative image of Ukraine abroad, forcing the state to make the concessions for a long time and to balance between the Russian Federation and the EU. It is necessary for Ukraine to create such political and economic conditions, where it will be possible to guarantee the equality of approaches to the realization of the bilateral cooperation and to reduce the energy dependence of the Ukrainian state. Therefore, the external energy policy of Ukraine 
should be based on the establishment of energy safety, with the further liquidation of dependence on the energy resource supplies from abroad, and at the level of the Ukrainian

- Russian relations a consumption of the Russian gas should be reduced by means of the supply diversification and the introduction of the effective energy and economic activities.

\section{Improvement of Russian Energy Strategy - 2015}

As a result of the sanctions imposition against the Russian Federation because of the annexation of Crimea, in 2015, the Russian government took the decision to amend the energy strategy for the period until 2035, in order to maintain the strategic development of the Russian energy sector according to the new tasks and the state priorities. For the majority of countries, it was explained as an attempt to conduct the diversification of energy structure, to develop the not-carbohydrate energy sources and to use nonconventional kinds of fuel. Thus, the Russian experts note that a delay of demand growth for the import of hydrocarbons and the emergence of the new producers of hydrocarbons from the Persian gulf, Brazil, Australia, Central Asia, and also Northern America, which till 2020 can refuse to import and turn into the net exporter of the liquefied natural gas, considerably narrowing the market niches for the Russian Federation (The Government of the RF, 2015).

The Russian analysts mark also that the perspectives of rise in export of the Russian energy in the European direction will be diminished owing to the reduction in demand and the probable gains in the Asian direction are limited, because of a lack in the export infrastructure and a need of big investments into its development. It is possible to add the rise in the cost of capital and the restriction on the access to the external investments and technologies, through the sanctions imposition against Russia. So, in the foreseeable future, the Russian external energy policy will be aimed at the preservation and strengthening of the country's positions on the global energy market, decreasing the risks and increasing the efficiency of the foreign trade activities of the Russian companies 
(which work in the fuel and energy complex), and also the diversification of directions of the Russian energy export (The Government of the RF, 2015).

In particular, in the Russian Energy Strategy till 2035 aimed at taking foreign policy decisions such as: the development of new forms of the international business in energy sphere, strengthening of the Russian companies' positions abroad, and also the foreign companies with the large Russian segment, including an access to the foreign markets of energy resources; the improvement of coordination mechanisms of the external energy policy of Russia with other actors at the energy markets for maintenance of the stable and expected conditions of cooperation; the formation of common market of energy carriers within the Eurasian Economic Union on the basis of introduction of the common regulation principles in the energy area. For the fulfilment of the named targets, were defined the key partners. Among them are the member-states of the EEU, the CIS, the EU, Shanghai Group, BRICS, ASEAN and added the countries in the Black Sea, Caspian and Arctic regions, Northern and Latin America, and the other international organizations; the active dialogue with the EU, regarding the participation of Russia in the transformation of the European gas market in the common interests of both, and with the Asian consumers of the Russian energy resources (The Government of the RF, 2015).

For protection of the state interests, the Russian scientists offered the strategy "Razvitie" (2015). They proposed the idea that will help to transform the Eurasian space under the Russian requirements. The role of Russia is reduced not because of the capitalization of its transit potential and the formation of new public benefits, but on the basis of the general development of all civilized centres, neighbouring with Russia. In the long term, it is planned to create a platform, "the Eurasian belt", with the participation of the EU member-states, Russia, China, Japan, India, Republic of Korea, Kazakhstan, Ukraine, Belarus, CIS countries; a platform, "the Latin American belt", with the participation of Brazil, Columbia, Chile, Peru, Argentina; "the Eurasian American belt", for the connection of Alaska (the USA) with Chukotka (Russia); "the African belt", with 
the participation of the Republic of South Africa, Angola and other countries of the continent. The deepening of transcontinental cooperation should occur on the basis of the equal rights maintenance and the participation of international actors, whereas the Russian variant of cooperation accepts only the leading role of Russia and doesn't take into account the interests of the other participants.

Apart from the maintenance of the Russian national interests in the energy sphere, it is supposed to enhance the negotiations on consolidation of the international balance of interests of exporting, importing and transit countries as well as the political and economic support of the Russian export of technologies and services; the creation of favourable taxation, tariff and customs conditions for the diversification of Russia's export; the assistance in purchase of the international energy assets $s$ by the Russian companies in the spheres of extraction, processing and selling, and also their participation in the international infrastructural projects for the expansion of the export-import transactions in the field of traditional and "green" electric power; the maintenance of the international legal registration of the external border of the Russian continental shelf in the Arctic ocean, in order to develop the sea oil-and-gas resources; the coordination of the Russian energy policy with the long-term plans and strategy of other participants at the energy markets (The Government of the RF, 2015).

In future, Russia will try to use its monopoly position in relation to the possession and producing of energy resources as to bring pressure upon both, Ukraine and the EU. According to the Russian Federal Agency for Resource Use, the total stocks of "blue flam gas" account for approximately 65 billion of cubic metres and the annual output of gas production is up to 600 billion of cubic meters, estimating that about 430 billion is intended to the domestic consumption and 170 billion to the export. In 2012-2014, Russia, together with the Saudi Arabia, shared the first and second places in the world in relation to oil recovery, including gas condensate (12.7 and $12.9 \%$ respectively). In the natural gas extraction, Russia $(19.6 \%$ in $2013,16.7 \%$ in 2014$)$ conceded only the USA $(21.4 \%$ of 
world extraction in 2014). Russia ranked the sixth place for the coal mining (4.3\%), and the third place by the export turnover, whereas in nuclear power the USA (33.1\% of world production) were holding the leading positions, while Russia lay in the third place $(7.1 \%)$ (The Government of the RF, 2015).

With an active involvement of the Russian state in the world energy market, such Russian oil-and-gas corporations as "Gazprom oil", "Gazprom", "Transneft", "Lukoil" were pushing forward, and the company "Zarubezhneft" with the state control packet of shares in "Rosneft", exclusively produces, transports and carries out the oil refining and natural gas extraction in Central and Eastern Europe, Middle East, Southeast Asia and Latin America. It is necessary to point out the activity of "United Power Systems", which provide the supplies of electric power to Finland, Belarus, Lithuania, Georgia, Azerbaijan, Kazakhstan, China, and Mongolia. It must be noted that, in the atomic energy sphere, only the state corporation "Rosatom" carries out a complete production cycle and deliveries of atomic energy worldwide (The Government of the RF, 2015). The external energy policy is a powerful component of the international cooperation of Russia and is connected with the processes of foreign policy decision-making in the state.

\section{The Ukrainian view on the Russian goals in the energy area}

The revised Russian energy strategy is guided by the construction of new export gas corridors to the Asian countries, sea energy terminals in the East, Northwest and North, what, in our opinion, is a threat to the national interests of Ukraine, because of congestion of the Ukrainian transportation systems and their uninterrupted functioning can be affected. Today Russia uses the energy recourses and pipelines as a tool of political influence, which, at the same time, is a factor of the carbohydrate streams destabilization in the direction of the East - West and impairs the stable operation of pipelines of the transit states, first of all Ukraine.

The Ukrainian experts share one view that an interest of Russia in the Ukrainian 
gas-transport system and underground gas storehouses is much more important than the infrastructure as such. This will ensure the maintenance of a key role in managing the gas streams during peak demand that cannot be guaranteed by any of the offered routes of gas mains bypassing Ukraine (Gonchar, 2012). In this case, the threats to the national interests of Ukraine can be the following: a decline of gas extraction in Russia due to the reserves depletion in the Western Siberia and an inability to deliver "Yamal" and "Shtokman projects", which will lead to the loss of opportunities to prime the Ukrainian pipeline system; a refusal of the EU to increase the import of the Russian gas, replacing it with the American and Arabian liquefied natural gas and developing the European slate gas deposits; a critical excursion of the Russian pipeline capacities as a counter to the level decrease of their excursion, which will allow to manipulate volumes, streams and prices of deliveries.

The Ukrainian experts consider that the Russian energy policy is aimed at the implementation of the absorbing script, establishing the sphere of influence in the postSoviet space. As an example of it, is the Belorussian case, when $100 \%$ of "BelTransGas" share package were transferred to Russia. Besides the rise in efficiency of the Russian pipeline capacities, it can lower the level of functioning of the Ukrainian gas-transport system, especially under the conditions of the slumping demand in Europe (Gonchar, 2012).

Thus, the system of gas export diversification helps Russia to create the permanent mechanism of pressure on one or another country through the threat of supply restraint or cessation of energy resources. For example, the available system of pipelines, the longterm contracts and networks of the Russian affiliated companies in energy sphere allow to manipulate the states in Central and Eastern Europe, and Germany, what will become a challenge to the regional and national energy safety as well (Gonchar, 2013). 
Issue no. $22 / 2017$

\section{Russian energy perspectives in the nearest future}

In 2016, the EU has started the construction of the Trans Adriatic pipeline, which gives a chance to the countries in Central and Southern Europe to have the alternative source of gas deliveries. According to the specialist research, there are no guarantees that the new pipeline will be filled chock-a-block. At the same time, "Gazprom" plans to launch the gas main "Northern stream - 2" to Germany by the end of 2019 and begins the negotiations on the project "Poseidon" (a gas main to Greece via the Black sea with capacity of 12 billion cubic metres), designed in Italy, which is the second European consumer of the Russian gas after Germany (Mahneva, 2016). However, the functioning of pipelines branches is limited and the cessation of the Russian gas deliveries via Ukraine will cause the decrease of offers, while Norway and the USA are ready to sell it at the below-cost price with the purpose to unload the home market for their own benefit. Therefore, Ukraine should try to keep at the European gas market, because a loss of each cubic meter will lead to the political and economic concessions (Koroleva, 2016).

Under the conditions of preservation of tendencies to reduction of volatility of the EU, the continuation of the sanctions imposition against Russia within 2017-2019 is predicted. The rigid restrictions of access of the Russian companies to the world capital market will suspend the economic development of the state. Therefore, the Russian scientists offered several scenarios for the parameters improvement of the federal budget for 2017-2019, which were approved at the governmental session in April, 2016 (The Ministry of Economic Development of the RF, 2016). More precisely, the forecast of the social and economic development of Russia has three versions - basic, target and conservative. The first one is taken as basis for planning the budget 2017-2019, thus the parameters of basic and target scenarios in energy sphere coincide.

The development scenario of Russia is characterized by the preservation of the conservative tendencies in changing-the external factors for the energy sphere and sticking to the traditional budgetary policy. The Russian experts define the federal budget of Russia 
as deficit-ridden till 2019. The reasons resides in the reduction of oil-and-gas incomes, which will require the increase of efficiency of the state expenses, the annual reduction of budgetary expenses for $5 \%$ therefore it is planned. Beyond that, a safety of the economic development of the state leads to the additional mobilization of all possible resources through the attraction of the internal and external loans and privatizations of the state property (The Ministry of Economic Development of the RF, 2016). In the target scenario, experts plan to transform the Russian economy according to the investment model in 2017. Also, the gas rates are necessary for the dynamic growth, which will not be reached, because of the inertness of investment process and the funding constraints. At the same time since 2018 due to the reduction in interest rates and the creation of favourable conditions for the crediting business, the investment projects will ensure economic growth and improve the efficiency of economy up to $4.5 \%$ in 2019 (The Ministry of Economic Development of the RF, 2016).

Within the framework of the conservative scenario, the development of Russian economy is planned to occur under the conditions of low dynamics of prices for oil and natural gas. It is supposed that the mid-annual price for oil in 2016 will fall down to 25 dollars for barrel and stabilize at this level till 2019. Therefore, in view of the low prices for oil and high exchange rate volatility of rouble, the basic macroeconomic parameters in 2016 have negative dynamics: the gross national product shrinks up to $2.1 \%$, the disinvestment - up to $9.4 \%$, the rise in inflation in comparison with a basic variant - up to $9 \%$, the further falling of incomes and the declining living standards. Whereas in 2017 the experts predict some stabilization of the Russian economy with suspension of rates impairment up to $0.4 \%$, and in 2018-2019 the tendency of continuous growth at the level of $0.7-1.6 \%$ is planned. Thus, owing to the low price for oil, the reduction in oil-and-gas incomes of the federal budget, will lead to its deficiency, a scale exhaustion of the accessible budgetary funds and an increase in a public debt. That is why for the balancing of the federal budget since 2017 , the reductions of expenses for $10 \%$ will be conducted 
(The Ministry of Economic Development of the RF, 2016).

Proceeding from the outlined tendencies of the economic development of Russia, we observe the direct interdependence between the prices for hydrocarbon and the dynamics of the economic growth. The Russian experts approve that now it is possible to predict the decrease in extraction of the Russian hydrocarbons in 2019 up to 532 million tons, because of the decrease in oil recovery in the Western Siberia. Among the reasons of recession and the reduction of dynamics of the hydrocarbons extraction, are named the absence in Russia of the necessary competency for carrying out of shelf and technically difficult projects and also the import restriction of equipment and technologies for their delivery. Due to the growth of internal gas consumption, the extractions of natural gas in Russia in 2019 are estimated by the Russian experts at 676 billion cubic metres (The Ministry of Economic Development of the RF, 2016).

The implementation by EU countries of policy, oriented to the reduction of dependence on the Russian gas import and its replacement with its own internal energy resources, will lead to the export reduction in comparison with 2015, thus the Russian gas supplies to Ukraine during the specified period are estimated at no more than 11 billion cubes. Under the conditions of the gas consumption restrictions and the incomplete use of the available investment capacities of "Gazprom", the deposits decreased in 2016, therefore the output of Yakut gas can become an alternative to the gas streams to East Asia, first of all China. Thus, the main project, which will provide with the predicted extraction volume, can be a gas main «Force of Siberia» that will pass through the territory of Irkutsk area, Republics Sakha (Yakutia), to the Amur area, the Jewish autonomous region and Khabarovsk territory, and will allow to deliver gas to the consumers of the Russian Far East and China (The Ministry of Economic Development of the RF, 2016).

Proceeding from the forecasts of the economic development of Russia, the political and economic dependence of the state on energy resources export, it is possible to expect the realization of permanent or ad hoc cooperation between Ukraine and Russia, not only 
in the energy sphere, but also at the political level. Thus, the preservation of the EU and the USA sanctions against Russia, will lead to the decrease in rates of the innovative development of the country, which will designate its ability to enhance the foreign policy course.

\section{Conclusions}

The energy resources are used by Russia as one of the tools of conducting hybrid war against Ukraine and the energy infrastructure became an object of foreign conquest. The Ukrainian analysts consider that the government should take a complex of measures, aiming at a decrease of the negative consequences. It is important to revise contracts, concerning a supply of the Russian gas to Ukraine, to develop a single Ukrainian European approach in respect of the interaction with the Russian Federation, and also to return the Ukrainian oil-and-gas assets to Crimea, the Black and Azov seas. The prospects of bilateral cooperation in the energy sphere were also defined by the domestic experts; more precisely, they purposed: to minimize the energy dependence of Ukraine through the transformation of the state-to-state interaction, instead of its intensification; to adopt the European energy legislation in Ukraine in order to prevent the Russian Federation from applying the non-transparent approaches in the power sector; to reduce the Russian energy resources import; to create the strategic reserves of mineral oil, gas, coal, nuclear fuel as to increase Ukraine's resistibility to the Russian energy blockade.

As to ensure the bilateral interaction between Ukraine and Russia, taking into account the national interests of the Ukrainian state, was offered (The relations Ukraine RF, 2014): in oil-and-gas sphere to continue reverse-flow deliveries of gas from the EU through Poland, Slovakia, and Hungary; to promote the use of floating installation for storage of natural gas and the supply of the liquefied gas to Ukraine from the Black Sea region; to integrate the Ukrainian gas-transport system to the European power network; to involve the European and American investors in management of the Ukrainian gas- 
transport system; to reform "Naftogas"; to conclude contracts with the EU member-states concerning a transit of the Russian gas via Ukraine and to transfer a gas delivery point to the Ukrainian eastern border; in the coal industry, to organize a supply of imported coal; in the field of atomic engineering, to strengthen the cooperation with the USA on the issues of diversification of the nuclear fuel sources; in the power area, to carry out the independent audit of the hydrocarbons extraction sector; to launch the national projects in relation to the reduction of natural gas consumption through the use of the alternative energy sources and the level increase of national energy economy; to switch to the market price for gas, which is the same for all consumers; to separate functions from sale and distribution of electric power.

Within the context of initiating of "the limited partnership" format in political, economic and energy interaction between Ukraine and Russia, offers have also been made to the European Union, which can force Russia, because of its almost one-way oriented energy export (focused on the European market), to provide the country's reserve stocks. Therefore, the EU can take the decision on reduction and replacement of the Russian gas, oil, mineral oil and coal import; to freeze a construction of the nuclear energy units upon the Russian project on the territory of the EU member-states; to launch an investigation of the Russian state and private energy companies with off-shore registration within the limits of the European legislation. Thus, a lifting of sanctions in relation to Russia, in the opinion of the Ukrainian experts, is possible only under the conditions of the permanent monitoring of gas stations on the border, the control over the movement of gas streams, intended to export to the EU; a demonopolization of the Russian energy sector and an admission of the independent producers on the foreign markets; an assurance of free transit of the CentralAsian gas to the EU territory; a return of Russia to the provisions of the Energy Charter Treaty (Gonchar, 2015, p. 89).

In the short-run, Russia will try to maintain the exclusive positions of the hydrocarbons supplier to Europe through the destabilization of the Caspian, Asian regions 
in the Middle, establishing the direct or indirect control over the alternative routes. Therefore, despite the worsening of economic conditions, the Russian Federation will attempt to carry out such gas-transport projects as "Turkish Stream" and "Northern Stream - 2" - by-passing Ukraine and Slovakia as key elements of the corridor Siberia - Europe; to impede the construction of Trans-Caspian gas pipeline for the Turkmen gas; not to allow the delivery of projects on energy resources transit from the Middle East through Syria; to supervise or destabilize Azerbaijan as the alternative supplier of gas; Algeria as the competitor, who develops new Sahara carbohydrate deposits; Saudi Arabia as the powerful actor at the world oil market, and also Kazakhstan, because of annexed areas, where are carrying out the basic international oil-extracting projects; to establish the control over the Western sector of the Arctic regions, not recognizing the occupation of archipelago Spitsbergen, which officially belongs to Norway (Gonchar, 2015, p. 90).

In the long-term, it is possible to expect the economic stagnation in Russia. It will prevent from carrying out projects, aimed at renovating of the Russian energy sector, thus Ukraine and the EU have a diversification opportunity in respect of the energy resources through the development of the nuclear energy production, a use of the alternative energy sources, a technological modernization of the energy sector for extraction of slate gas, a rebuilding of the transport and energy-economic infrastructures.

The perspectives of an interaction between Ukraine and Russia in the energy sector are based on the successes of the Ukrainian government in its reforming and also if these processes are supported by the EU and the USA. The medial position of Ukraine concerning Russia and the EU, allows to conduct the external energy activities, even under the conditions of preservation of the political and economic independence of the Ukrainian state; the economic indulgence of the Russia can be used for conducting of the constructive negotiations in energy area at the level of Ukraine, the EU and the Russian Federation, because the continuations in sanctions will make the modernization of both the Russian energy sector, and of the economy in general, just impossible. So, one expects that Russia 
will lose the opportunities to increase the production of energy resources, diminishing capacities of deposits, reducing the prices on oil, gas and implementing the EU energy programs; the decrease in the Russian pressure on the world energy market with a view to minimize its influence at the regional European and Central-Asian level, is directly connected with the flexibility and efficiency of the foreign policy course of the USA in the Middle East and Central Asia, or on the contrary, the expectation of escalation of the internal political conflicts in Caucasus, Central Asia and Middle East, incited by the Russian Federation in order to fail the energy deliveries to the EU. So, the internal activation of the Russian investment reserves as to develop the nuclear and coal areas, to construct the modern hydroelectric power stations and to expand the supply infrastructure of all kinds of energy resources, is possible. This should help the state to get rid of the unilateral dependence on the hydrocarbons export, thus Ukraine could modernize its own energy area up to the European standards, keeping itself safe from the probable renewed energy pressure on the part of Russia.

\section{References}

- GONCHAR, M. (2015), "Energy aspects of relations of Ukraine - RF in the context of Russian Aggression of Hybrid Type against Ukraine”. National Security and Defence, № 8-9, pp. 88-91.

- GONCHAR, M. (2013), "Metamorphoses of gas markets of the EU and the RF: conclusions for Ukraine". Kiev International Energy Club, 5th June. Available from: http://www.qclub.org.ua/analytics/metamorfozy-hazovyh-rynkiv-es-ta-rf-vysnovky-dlyaukrajiny/ (Accessed 27/02/17).

- GONCHAR, M. (2012), "New energy potential of Ukraine". Kiev International Energy Club, 17th Dec. Available from: http://www.qclub.org.ua/analytics/novij-energetichnijpotencial-ukra\%D1\%97ni-mixajlo-gonchar/ (Accessed 27/02/17). 
- KNYAZHANSKIY, V. (2016), "Histories of gas wars”. The Day, № 32. Available from: http://day.kyiv.ua/uk/article/ekonomika/istoriyi-gazovyh-voyen (Accessed 27/02/17).

- KOROLEVA, A. (2016), "Ukraine stays Europe without gas”. Expert Online, 23rd Aug. Available from: http://expert.ru/2016/08/23/tranzit/ (Accessed 27/02/17).

- MAHNEVA, A. (2016), "Europe starts to build a pipeline - a concurrent of projects of Gasprom". Business News Media, 17th May. Available from: http://www.vedomosti.ru/business/articles/2016/05/18/641387-evropa-konkurent-gazproma (Accessed 27/02/17).

- MAZUREC, Y. and RYZHKOV, M. (2014), "The influence of energy politics on UkrainianRussian interstate relations”. Problems of International Relations, Issue 8, pp. 60-72.

- Naftogas of Ukraine (2016), The question about activities of the company Naftogas. Available from: http://www.naftogaz.com/www/3/nakweb.nsf/0/A54B831D85568C37C2257FA000329861?O penDocument (Accessed 27/02/17).

- PIROZHKOV, S. (ed.) (2001), Ukraine and Russia in the system of international relations: strategic perspective. Kiev: NIPMB.

- The Government of the Russian Federation (2015), Energy strategy of Russia till 2035 Available from: www.energystrategy.ru/ab_ins/source/ES-2035_09_2015.pdf (Accessed 27/02/17).

- The Ministry of Economic Development of the Russian Federation (2016), Scenario conditions, main parameters of prognosis of socio-economic development of the Russian Federation and limit levels of prices (tariffs) on services of companies of infrastructural sector in 2017 and in the plan period 2018-2019. Available from: www.economy.gov.ru/wps/wcm/connect/d8297656-48da-4d60aec31d3d27ee908e/\%D0\%A1\%D1\%86\%D0\%B5\%D0\%BD\%D0\%B0\%D1\%80\%D0\%BD\% D1\%8B\%D0\%B5+\%D1\%83\%D1\%81\%D0\%BB\%D0\%BE\%D0\%B2\%D0\%B8\%D1\%8F201 7_2019.pdf (Accessed 27/02/17). 
- The Ministry of Foreign Affairs of Ukraine (2016), Treaty base of bilateral UkrainianRussian relations. Available from: www.mfa.gov.ua/mediafiles/sites/russia/files/DogovirnaBaza.doc (Accessed 27/02/17).

- The relations Ukraine - RF: perspectives, conceptual approaches and practical steps (2014), National Security and Defence, № 5/6, pp. 27-40. 